\title{
Analisis Penerapan Balanced Scorecard Pada PT. Sarana Gadai Prioritas Musi Banyuasin
}

\author{
Santi Puspita \\ Fakultas Ekonomi Universitas PGRI Palembang, \\ Email : santipuspita@univpgri-palembang.ac.id
}

\begin{abstract}
ABSTRAK
Penelitian ini mengenai "Analisis Penerapan Balanced Scorecard Pada PT Sarana Gadai Prioritas Musi Banyuasin". Dengan adanya balanced scorecard sebagai analisis kinerja dalam perusahaan PT Sarana Gadai Prioritas Musi Banyuasin sangat membantu perusahaan untuk mencapai dan mengetahui tujuannya baik secara efektif maupun efisien. Hal ini berdasarkan pada konsep balanced scorecard yang tidak hanya menilai baik dari keuangan melainkan dengan non keuangannya juga. Dengan menggunkan empat perspektif yaitu: perspektif keuangan, perspektif pelanggan, perspektif bisnis internal dan perspektif pembelajaran dan pertumbuhan. Pengukuran data pada penelitian ini adalah menggunakan data kuantitatif, data kuantitatif yaitu pengukuran dengan menggunakan rasio-rasio dari empat perspektif di atas.

Hasil penelitian ini adalah pada perspektif keuangannya dikatakan baik karena walaupun setiap tahun tidak mengalami kenaikan namun pada tahun terakhir meningkat secara signifikan dan pada biaya operasionalanya setiap tahun menurun ini berdampak baik pada perusahaan. Pada perspektif pelanggan ini sangat baik karena baik loyalitas pada pelanggan lama ataupun pelanggan baru setiap tahun meningkat . pada perspektif bisnis internal pada eprspektif ini menunjukkan keadaan yang baik untuk perusahaan karena berdasarkan inovasi dan operasi perusahaan selalu mencoba meningkatkan pelayanan yang baik pada pelanggan dan pada ketepatan waktu atas transaksi yang dilakukan (AETR) sedikit mengalami penurunan pada tahun terakhir. Dan pada perspektif pemebelajaran dan pertumbuhan perusahaan mencoba meningkatkan profesionalisme pegawai dan meningkatkan pengawasan dan budaya patuh pada aturan.
\end{abstract}

\section{Kata Kunci : Pengukuran Kinerja Menggunakan Pendekatan Balanced Scorecard}

\section{A. Latar Belakang}

Tujuan suatu perusahaan didirikan adalah untuk menciptakan kekayaan. Untuk mencapai tujuan tersebut, perusahaan harus memiliki produk yang dapat dijual kepada Masyarakat. Produk adalah sesuatu yang dihasilkan oleh perusahaaan yang dapat di jual kepada masyarakat sebagai sumber pendapatan bagi perusahaan. Produk tersebut dapat berupa produk-produk non-fisik (jasa) atau bahan barang jadi yang siap digunakan. Untuk mengelola sumber daya dalam rangka mencapai tujuan perusahaan, biasanya perusahan menyerahkan kepada para manajer yang bekerja penuh, untuk bekerja sepenuhnya pada perusahaan ini. Keberhasilan para manajer ini biasanya di nilai dari prestasi keuangan perusahaan.

Tetapi, melalui pemantauan dari waktu ke waktu terlihat bahwa sistem Penilaian Kinerja Manajemen yang hanya berbasis pada satu tolak ukur keuangan saja, akan menimbulkan permasalahan dalam jangka panjang. Ukuran kinerja manajemen yang hanya mengandalkan kinerja keuangan jangka pendek umumnya mencakup satu tahun, akan mengakibatkan eksekutif lebih menfokuskan perwujudan kinerja jangka pendek. Karena itu, kinerja non-keuangan perlu mendapatkan perhatian yang lebih 
banyak demi tercapainya tujuan jangka panjang perusahaan.

Dengan adanya perkembangan tersebut, maka dibutuhkan sesuatu pengukuran kinerja yang mengukur kinerja secara lebih akurat mencakup aspek yang mempengaruhi kinerja organisasi. Menurut Rivai (2011:554) “ kinerja merupakan prilaku yang nyata yang ditampilkan setiap orang sebagai persentasi kerja yang dihasilkan oleh pegawai sesuai dengan perannya dalam perusahaan“. Kinerja karyawan harus diarahkan kepada suatu hasil yang diharapkan perusahaan tesebut yaitu, kinerja ynag memberikan kontribusi untuk menjadikan perusahaan sebagai pencipta kekayaan. Pengukuran kinerja merupakan salah satu faktor yang amat penting bagi sebuah perusahaan, serta sebagai dasar penyusunan imbalan pada perusahaan.

Selama ini pengukuran kinerja secara tradisional harus menitikberatkan pada sisi keuangan, karena pengukuran ini mudah dilakukan sehingga personel yang diukur hanya yang berkaitan dengan keuangan. Seperti kinerja peningkatan kepercayaan perlanggan terhadap layanan jasa perusahaan peningkatan kompetensi dan komitmen personel, dan peningkatan cost effectiveness, proses bisnis yang digunakan melayani customer, diabaikan oleh menajemen karena sulit pengukurannya. Melihat adanya kekurangan yang ada, maka pengukuran secara tradisional dianggap tidak memadai.

Menurut Wibowo (2010:7) "kinerja adalah tentang melakukan pekerjaan dan hasil yang dicapai dari pekerjaan tersebut". Sedangkan menurut Benardin dan Russel yang diterjemahkan oleh Khaerul Umam (2010:190-191) "penilaian kinerja adalah cara mengukur kontribusi individu (karyawan) pada organisasi tempat mereka bekerja". Kinerja perusahaan tidak lagi dianggap jika hanya dilihat laporan keuangan yang dihasilkan, hal ini karena ukuran yang mudah untuk dilakukan pengukurannya. Karena pengukuran keuangan yang mudah untuk dilakukan, maka kinerja personel yang diukur hanyalah yang berkaitan dengan keuangan. Ukuran-ukuran finansial saja tidak mampu mencerminkan kompleksitas dan nilai yang melekat dalam perusahaan dengan Orientasi Proses. Oleh karena itu untuk mengatasi kekurangan ini, maka diciptakan suatu metode pendekatan yang mengukur kinerja perusahaan dengan konsep Balanced Scorecard.

Konsep Balanced Scorecard merupakan suatu sarana untuk mengkomunikasikan persepsi strategi dalam perusahaan secara sederhana dan mudah dimengerti oleh berbagai pihak dalam perusahaan, terutama pihak-pihak dalam organisasi yang akan merumuskan strategi perusahaan. Pengertian Balanced Scorecard sendiri jika diterjemahkan bisa bermakna sebagai rapor kinerja seimbang (Balanced). Scorecard adalah kartu yang digunakan untuk mencatat skor hasil kinerja seseorang dan/atau suatu kelompok, juga untuk mencatat rencana skor yang hendak diwujudkan. Dengan demikian, dapat dikatakan bahwa penerapan konsep Balanced Scorecard sangat berpengaruh terhadap pencapaian tujuan perusahaan sebab Balanced Scorecard yang telah dilakukan dapat menghasilkan perbaikan dan perubahan strategis yang dilakukan untuk mencapai kinerja yang akan dicapai dalam pengelolaan unit usaha perusahaan.

PT Sarana Gadai Prioritas Musi Banyuasin merupakan perusahaan yang bergerak dibidang jasa atau perusahaan simpan pinjam dengan 
sistem gadai sebagai modal usaha dengan memberikan barang jaminan berupa barang berharga seperti (emas, BPKB motor/mobil), perusahaan ini belum menerapkan pengukuran kinerja Berdasarkan Konsep Balanced Scorecard.

\section{B. Rumusan Masalah}

Demikian dapat ditarik kesimpulan atas rumusan masalah yang di maksud oleh penulis berdasarkan latar belakang di atas yaitu "Bagaimana penerapan Balanced Scorecard sebagai Alat ukur kinerja pada PT Sarana Gadai Prioritas Musi Banyuasin?"

\section{Metode Penelitian}

Menurut Sedamaryanti (2011:115) : "metode penelitian sangat diperlukan supaya perolehan dapat diarahkan pada sasaran dan tidak menyimpang dari tujuan yang diharapkan".

Sumber data dalam penelitian ini yaitu data sekunder. Data sekunder adalah data yang diperoleh lewat pihak lain, tidak langsung diperoleh dari subjek penelitian.

\section{Populasi dan Sampel}

\section{1) Populasi}

Menurut Sugiyono (2010:38) : populasi penelitian adalah "suatu atribut atau sifat dan nilai dari orang, objek atau kegiatan yang mempunyai variasi tertentu yang ditetapkan oleh peneliti untuk dipelajari dan kemudian ditatik kesimpilan".

Populasi penelitian merupakan permasalahan yang diteliti. Objek dari penelitian ini alat Balance Scoercard yang meliputi perspektif keuangan, perspektif pelanggan, perspektif bisnis internal dan perspektif pertumbuhan dan pemebelajaran. Penelitian ini dilakukan pada PT Sarana Gadai Prioritas Musi Banyuasin.

\section{2) Sampel}

Menurut Sugiyono (2010:215) : "sampel adalah sebagian dari populasi itu". Adapun yang menjadi sampel pada penelitian ini yaitu laporan keuangan neraca dan laporan laba rugi, data nasabah, dan data prosfektif, dari tahun 2014, 2015 dan 2016, dengan menggunakan penghitungan berdasarkan empat perspektif dari Balance Scorecard.

\section{E. Teknik Pengumpulan Data}

Menurut Sugiyono (2010:223) : "istrumen adalah yang lebih penting. Namun pengumpulan data yang digunakan oleh peneliti adalah lebih penting". Tehnik pengumpulan data yang digunakan pada penelitian ini adalah :

\section{a. Dokumen}

Teknik dokumen adalah dengan cara meminta data perusahaan yang berhubungan dengan masalah yang akan di teliti sehingga sesuai dengan tujuan penelitian.

b. Studi pustaka

Merupakan tehnik pengumpulan data berdasarkan sumber-sumber yang diperoleh dari leteratul yang membahas mengenai pengukuran kinerja balance scorecard.

\section{F. Teknik Analisis Data}

Menurut Sugiyono (2010:278) : "pekerjaan analisis data meliputi tiga langkah yaitu : persiapan, tabulasi, dan penerapan data sesuai dengan pendekatan penelitian". Analisis data yang digunakan pada penelitian ini adalah analisis kuantitatif, yaitu data yang berbentuk angka. Teknik analisis data yang akan di gunakan dalam penelitian ini yaitu menyajikan angka, table, dan uraian penjelasan mengenai pengukuran kinerja dengan mengunakan empat perspektif Balance Scorecard. 
Menurut Mulyadi (2011:22) : "tentang rasio keuangan yang digunakan dalam perhitungan keuangan dan non keuangan pada Balanced Scorecard :

1. Perspektif Kuangan
a. ROI
$=$ $\frac{\text { Laba bersih }}{\text { total aktiva }} \times 100 \%$
b. BOPO

$$
\frac{\text { Biaya operasional }}{\text { pendapatan operasional }} \times 100 \%
$$
c. Current ration =

$$
\frac{\text { aktiva lancar }}{\text { pendapatan operasional }} \times 100 \%
$$

2. Perspektif pelanggan

a. Customer acquisition = $\frac{\text { jumlah pelanggan baru }}{\text { total jumlah pelanggan }} \times 100 \%$

b. Customer retention= $\frac{\text { jumlah pelangga lama }}{\text { total jumlah pelanggan }} \times 100 \%$

3. Prespektif Proses bisnis internal

a. Inovasi

b. Proses operasi

4. Perspektif pembelajaran dan pertumbuhan

a. Reterensi karyawan= $\frac{\text { jumlah karyawan keluar }}{\text { total jumlah karyawan }} \times 100 \%$

b. Produktivitas karyawan $=$ $\frac{\text { laba bersih }}{\text { total jumlah karyawan }} \times 100 \%$

\section{G. Hasil Penelitian}

Balanced scorecard merupakan pengukuran kinerja yang digunkan untuk mendongkrak kemapuan operasioanl dalam melipat gandakan kinerja keuangan, oleh karena itu organisasi pada dasarnya adalah instansi pemerintah kekayaan, pengunaan Balanced Scorecard dalam pengelolaan perusahaan menjanjikan peningkatan signifikan kemampuan organisasi dalam menciptakan kekayaan. Penilaian kinerja dengan menggunakan Balanced Scorecard dapat dilakukan dengan menganalisa apakah sasaran dan target-target yang telah ditetapkan perusahaan dapat tercapai dengan perusahaan dapat tercapai atau tidak. Hal tersebut dapat memberi kemudahan pada perusahaan dalam menilai apa saja yang ingin di analisa baik secara keuangan atau tidak.

Menurut Rangkuti (2011:5-6) Balanced Scorecard terdiri dari empat pengukur kinerja yaitu :

1. Keuangan, untuk memberikan kinerja yang baik dari aspek keuangan kepada para stakeholder

2. Konsumen, untuk mengetahui bagaimana pelanggan menilai kita

3. Internal bisnis, untuk mengetahui keunggulan yang kita miliki

4. Inovasi dan pembelajaran, untuk mengetahui bagaimana kita melakukan perbaikan dan penyempurnaan secara terus menerus.

Melalui empat aspek Balanced Scorecard tersebut yaitu perspektif keuangan, perspektif pelanggan, perspektif bisnis internal, dan perspektif pembelajaran dan pertumbuhan yang merupakan sarana efektif untuk membangun pencapaian visi, misi, dan objektifitas PT Sarana Gadai Prioritas Musi Banyuasin.

\section{1) Persepktif Keuangan}

Dalam perspektif keuangan, kinerja perusahaan dinilai dari aspek keuangan yang dimiliki oleh perusahaan. Sasaran strategi yang ingin dicapai dengan penilaian kinerja keuangan adalah :
a) Meningkatkan
pendapatan perusahaan dengan memanfaaatkan asset yang dimiliki oleh perusahaan

b) Memberikan pelayanan yang produktif serta senantiasa selektif, sehingga akan berdampak pada peningkatan laba bersih perusahaan 


\section{Tabel 1}

Nilai Tolak Ukur Pada Perspektif Keuangan Berdasarkan Rasio Yang Digunakan

\begin{tabular}{|c|c|c|}
\hline Rasio & Penjelasan & Tolak Ukur \\
\hline $\begin{array}{l}\text { Return On Invesment } \\
\text { (ROI) }\end{array}$ & $\begin{array}{l}\text { Rasio ini merupakan rasio } \\
\text { keuangan } \\
\text { mempersentasikan seberapa } \\
\text { efektif asset perusahaan di } \\
\text { gunakan untuk menghasilkan } \\
\text { laba }\end{array}$ & $\begin{array}{l}\text { Semakin besar nilai rasionya, maka semakin } \\
\text { besar dana yang dapat dikembalikan dari } \\
\text { total asset perusahaan menjadi laba. Artinya, } \\
\text { semakin besar laba bersih yang diperoleh } \\
\text { semakin baik kinerja perusahaan. }\end{array}$ \\
\hline $\begin{array}{l}\text { Return On Equity } \\
\text { (ROE) }\end{array}$ & $\begin{array}{l}\text { rasio ini menunjukkan } \\
\text { besarnya pendapatan bersih } \\
\text { yang diperoleh perusahaan }\end{array}$ & $\begin{array}{l}\text { semakin besar nilai rasionya maka semakin } \\
\text { besar dana yang dapat dikembalikan dari } \\
\text { ekuitas menjadi laba. Artinya, semakin besar } \\
\text { laba yang diperoleh dari modal sendiri. ROE } \\
\text { tinggi akan menyebabkan posisi pemilik } \\
\text { modal perusahaan semakin kuat. }\end{array}$ \\
\hline $\begin{array}{ll}\text { Biaya } & \text { Operasional } \\
\text { Terhadap Pendapatan } \\
\text { Operasional (BOPO) }\end{array}$ & $\begin{array}{l}\text { Rasio yang digunakan untuk } \\
\text { mengukur perbanbandingan } \\
\text { biaya operasi, pendapatan } \\
\text { operasi. }\end{array}$ & $\begin{array}{l}\text { semakin kecil rasio ini berarti semakin efisien } \\
\text { biaya operasional yang dikeluarkan oleh } \\
\text { perusahaan yang besangkutan. Artinya, } \\
\text { semakin kecil angka rasio BOPO semakin } \\
\text { baik kondisi tersebut. }\end{array}$ \\
\hline Rasio & $\begin{array}{l}\text { Rasio yang digunkan dalam } \\
\text { perhitungan pada harta } \\
\text { lancar dan kewajiban lancar } \\
\text { untuk mengetahui } \\
\text { kemampuan perusahaan } \\
\text { dalam memenuhi kewajiban } \\
\text { jangka pendek. }\end{array}$ & $\begin{array}{l}\text { semakin tinggi nilai aktiva lancar semakin } \\
\text { tinggi juga perusahaan untuk menutupi } \\
\text { kewajiban jangka pendeknya. Rendahnya } \\
\text { rasio ini akan menunjukkan gejala likuiditas } \\
\text { dalam perusahaan namun sebaliknya terlalu } \\
\text { tinggi rasio ini menandakan bahwa banyak } \\
\text { dana yang menganggur (tidak berputar) }\end{array}$ \\
\hline
\end{tabular}

Sumber : Menurut Mulyadi (2011:22)

Adapun tolak ukur yang digunakan pada perspektif keuangan ini adalah :

a. Return On Investment (ROI) Merupakan Rasio Rentabilitas yang digunakan untuk mengukur kemampuan dari modal yang diinvestasikan dalam keseluruhan aktiva menghasilkan keuntungan netto, semakin tinggi nialai ROI berarti semakin baik kinerja perusahaan dalam memanfaatkan aktiva.

$$
\mathrm{ROI}=\frac{\text { laba Bersih }}{\text { Total Aktiva }} \times 100 \%
$$

ROI Tahun $2014=\frac{590.309 .443 .744}{1.123 .510 .451 .309} \times 100 \%$

ROI Tahun $2015=\frac{944.241 .044 .843}{1.331 .984 .281 .045} \times 100 \%$ $=77,89 \%$ ROI Tahun $2016=\frac{1.625 .633 .815 .740}{1.422 .069 .052 .484} \times 100 \%$

Hasil dari analisis ini adalah ROI pada PT Sarana Gadai Prioritas Musi Banyuasin Tahun 2014 sebesar 52,54 $\%$ berada pada tahap sedang, di Tahun 2015 mengalami kenaikan menjadi 77,89 \% dalam masa ini ROI tahun 2015 dalam keadaan baik, dan Tahun 2016 mengalami peningkatan lagi menjadi $114,3 \%$ karena brada pada tingkat sangat baik.

Berdasarkan pada perhitungan yang telah dilakukan di atas mengenai perspektif keuangan berdasarkan rumus ROI (Return On Investmen) berikut adalah perhitungan keuangan yang telah di rangkum menggunakan tabel sehingga mempermudah dalam memahaminya 


\section{Tabel 3}

Perhitungan Perspektif Keuangan

Dengan Mengunakan Rasio Return On Investmen (ROI)

PT Sarana Gadai Prioritas Musi Banyuasin Tahun 2014-2016

\begin{tabular}{|c|c|c|c|}
\hline Tahun & Laba Bersih & Total Aktiva & $\begin{array}{c}\text { Return On Investment ROI } \\
(3)=(2):(1)\end{array}$ \\
\hline 2014 & 590.309 .443 .744 & 1.123 .510 .451 .309 & $52.54 \%$ \\
\hline 2015 & 994.241 .044 .843 & 1.331 .984 .281 .045 & $77,89 \%$ \\
\hline 2016 & 1.625 .633 .815 .740 & 1.422 .069 .052 .484 & $114,3 \%$ \\
\hline
\end{tabular}

Sumber : PT Sarana Gadai Prioritas Musi Banyuasin di olah tahun 2017

Dalam penjelasan di atas bawasannya perspektif keuangan dengan mengunakan rasio keuangan Return On Investmen (ROI) Pada tahun 2014 sampai tahun 2016 ROI pada perusahaan ini selalu meningkat ini berdampak baik pada rasio keuangan perusahaan karena setiap tahun ROI nya meningkat secara signifikan.

\section{b. Return On Equity (ROE)}

Digunakan untuk mengukur kemapuan perusahaan dalam menghasilkan laba dengan memaksimalkan penggunaan ekuitas

$$
\mathrm{ROE}=\frac{\text { laba Bersih Setelah Pajak }}{\text { Modal sendiri }} \times 100 \%
$$

ROE Tahun $2014=\frac{590.309 .443 .744}{1.010 .021 .882 .984} \times 100 \%$ $=58,44 \%$

$$
\begin{gathered}
\text { ROE Tahun } 2015=\frac{994.241 .044 .843}{1.136 .621 .004 .302} \times 100 \% \\
=87,47 \%
\end{gathered}
$$

ROE Tahun $2016=\frac{1.625 .633 .815 .740}{1.232 .224 .668 .833} \times 100 \%$ $=131,9 \%$

Hasil dari perhitungan di atas adalah ROE pada PT Sarana Gadai Prioritas Musi Banyuasin Tahun 2014 sebesar 58,44 \%, di Tahun 2015 mengalam kenaikan menjadi $87,47 \%$, dan Tahun 2016 mengalami peningkatan lagi menjadi $131,9 \%$.

Berdasarkan pada perhitungan yang telah dilakukan di atas mengenai perspektif keuangan berdasarkan rumus ROE (Return On Equity) berikut adalah perhitungan keuangan yang telah di rangkum menggunakan tabel sehingga mempermudah dalam memahaminya.

Tabel 4

Perhitungan Perspektif Keuangan Mengunakan Rasio Return On Equity (ROE) PT Sarana Gadai Prioritas Musi Banyuasin Tahun 2014-2016

\begin{tabular}{|c|c|c|c|}
\hline Tahun & $\begin{array}{c}\text { Laba Bersih Setelah } \\
\text { Pajak }\end{array}$ & Modal Sendiri & $\begin{array}{c}\text { Return On Equity } \\
\text { (ROE) } \\
(3)=(2):(3)\end{array}$ \\
\hline 2014 & 590.309 .443 .744 & 1.010 .021 .882 .984 & $58,44 \%$ \\
\hline 2015 & 994.241 .044 .843 & 1.136 .621 .004 .302 & $87,47 \%$ \\
\hline 2016 & 1.625 .633 .815 .740 & 1.232 .224 .668 .883 & $131,9 \%$ \\
\hline
\end{tabular}

Sumber : PT Sarana Gadai Prioritas Musi Banyuasin di olah tahun 2017

Berdasarkan perhitungan di atas menggunakan rasio ROE maka dapat disimpulkan bahwa pada tahun 2014 hingga 2016 ROE pada perusahaan ini 
selalu meningkat, itu di dasarkan pada tahun 2014 ROE berada pada keadaan cukup baik, tahun 2015 ROE berada pada keadaan baik, dan tahun 2016 ROE berada pada keadaan sangat baik. Ini sangat berpengaruh positif pada keuangan perusahaan tersebut.

\section{c. BOPO}

Merupakan rasio yang digunakan untuk mengukur perbandingan biaya operasi, pendapatan opererasi yang diperoleh oleh pegadaian, semakin kecil angka rasio BOPO semakin baik kondisi tersebut,

$\begin{aligned} & \mathrm{BOPO}= \\ & \frac{\text { Biaya Operasioanal }}{\text { Pendapatan Operasional }} \times 100 \%\end{aligned}$
BOPO Tahun $\quad 2014$
$\frac{2.726 .182 .071 .110}{3.315 .211 .153 .911} \times 100 \%=82,23 \%$

$$
\begin{aligned}
& \text { BOPO Tahun } \begin{array}{c}
2015 \\
\frac{2.372 .994 .754 .711}{3.364 .862 .957 .661} \times 100 \%=70,73 \%
\end{array} \\
& \text { BOPO Tahun } \quad 2016 \\
& \frac{1.547 .571 .318 .911}{3.173 .205 .134 .651} \times 100 \%=48,76 \%
\end{aligned}=
$$

Dari perhitungan di atas biaya produksi pada tahun 2014 mencapai $82,23 \% \%$, dan pada tahun 2015 mengalami penurunan menjadi 70,73 $\%$, hingga tahun 2016 BOPO pada perusahaan ini mengalami penurunan menjadi $48,76 \%$.

Berdasarkan pada perhitungan yang telah dilakukan di atas mengenai perspektif keuangan berdasarkan rumus BOPO berikut adalah perhitungan keuangan yang telah di rangkum menggunakan table sehingga memper mudah dalam memahaminya :

\section{Table 5}

Perhitungan Perspektif Keuangan Menggunakan Rasio BOPO PT Sarana Gadai Prioritas Musi Banyuasin Tahun 2014-2016

\begin{tabular}{|c|c|c|c|}
\hline Tahun & Biaya Operasional & $\begin{array}{c}\text { Pendapatan } \\
\text { Operasional }\end{array}$ & $\begin{array}{c}\text { Bopo } \\
(3)=(2):(1)\end{array}$ \\
\hline 2014 & 2.726 .182 .071 .110 & 3.315 .211 .153 .911 & $82,23 \%$ \\
\hline 2015 & 2.372 .994 .754 .711 & 3.364 .862 .957 .661 & $70,73 \%$ \\
\hline 2016 & 1.547 .571 .318 .911 & 3.173 .205 .134 .651 & $48,76 \%$ \\
\hline
\end{tabular}

Sumber : PT Sarana Gadai Prioritas Musi Banyuasin di olah tahun 2017

Dari perhitungan di atas dapat di simpulkan bahwa pada tahun 2014 kondisi pada biaya operasional sangat meningkat dibandingkan dengan pendapatan, begitupun pada tahun 2015 biaya operasionalnya semakin meningkat ini mengakibatkan bahwa kondisi keuangan pada 2 tahun tersebut sedang tidak baik. Namun, pada tahun 2016 kondisi pendapatan operasionalnya membaik karena biaya operasionalnya menurun dibanding tahun sebelumnya.
Merupakan perbandingan aktiva lancar dan hutang lancar.

$$
\begin{aligned}
& \text { Current Rasio }=\frac{\text { Aktiva Lancar }}{\text { Hutang Lancar }} \times 100 \% \\
& =\frac{1.090 .399 .662 .248}{22.197 .617 .692} \times 100 \%=49,122 \% \\
& \text { Current Rasio Tahun } 2015 \\
& =\frac{1.226 .589 .778 .354}{13.623 .822 .792} \times 100 \%=90,032 \% \\
& \text { Current Rasio Tahun } 2016 \\
& =\frac{1.297 .589 .778 .354}{22.819 .287 .605} \times 100 \%=56,880 \%
\end{aligned}
$$

\section{d. Current Rasio}


Hasil dari perhitungan tersebut menunjukkan bahwa current rasio pada tahun 2014 sebesar 49,122 \%, dan mengalami kenaikan menjadi 90,032 \% pada tahun 2015 , dan kemudian tahun 2016 mengalami penurunan lagi menjadi $56,880 \%$.
Berdasarkan pada perhitungan yang telah dilakukan di atas mengenai perspektif keuangan berdasarkan rumus Current Rasio berikut adalah perhitungan keuangan yang telah di rangkum menggunakan table sehingga mempermudah dalam memahaminya.

Tabel 6

Perhitungan Perspektif Keuangan Menggunakan Current Rasio PT Sarana Gadai Prioritas Musi Banyuasin Tahun 2014-2016

\begin{tabular}{|c|c|c|c|}
\hline Tahun & Aktiva Lancar & Hutang Lancar & $\begin{array}{c}\text { Curent Rasio } \\
(3)=(2):(1)\end{array}$ \\
\hline 2014 & 1.090 .399 .662 .248 & 22.197 .617 .692 & $49,122 \%$ \\
\hline 2015 & 1.226 .589 .778 .354 & 13.623 .822 .792 & $90,032 \%$ \\
\hline 2016 & 1.297 .589 .778 .354 & 22.819 .287 .605 & $56,880 \%$ \\
\hline
\end{tabular}

Dari perhitungan di atas maka dapat dilihat pada tahun 2014 dan 2016 current rasio mengalami penurunan dibanding tahun 2015 yang meningkat sebesar 90,032 \%, itu di karenakan hutang lancar pada tahun 2015 lebih kecil dibandingkan pada tahun 2015 dan 2016 dapat dikatakan juga pada tahun ini banyak dana yang tidak berputar.

\section{2) Perspektif Pelanggan / Nasabah \\ Dalam perspektif ini nasabah} merupakan sebagian penyimpan dan peminjam dana, seperti perusahaan jasa simpan pinjam lainnya pada umumnya aktivitas utama PT Sarana Gadai Prioritas Musi Banyuasin. Menurut Rudianto (2013:240), Perspektif Pelanggan ini biasanya terdiri atas beberapa ukuran generic keberhasilan perusahaan dari strategi yang dirumuskan dan dilaksanakan dengan baik.

Sedangkan menurut Krismiaji (2011:370), di dalam Perspektif
Pelanggan pengukuran yang umum dilakukan atau digunakan adalah kepuasan pelanggan, jumlah pelanggan baru, kemampuan laba pelanggan dan pangsa pasar pada segmen tersebut.

Sasaran strategi yang ingin dicapai dengan kinerja perspektif pelanggan adalah :

1. Meningkatkan mutu pelayanan kepada nasabah, dengan tujuan agar meningkatkan kepuasan nasabah dan juga lebih meperhatikan nasabah yang ada

2. Meningkatkan jumlah fasilitas dan jumlah jaringan dengan tujuan menjangkau nasabah, dengan demikian tujuan meningkatkan jumlah nasabah dan pangsa pasar (market share) akan tercapai . berikut yang menjadi panduan untuk mencapai dan mengatahui loyalitas dari pelanggan : 
Tabel 7

Tolak Ukur Pada Perspektif Pelanggan yang Digunakan Dalam Perhitungan Keuangan PT Sarana Gadai Prioritas Musi Banyuasin

\begin{tabular}{|l|l|l|}
\hline Rasio & Penjelasan & Tolak Ukur \\
\hline $\begin{array}{l}\text { Customer } \\
\text { Acquisition }\end{array}$ & $\begin{array}{l}\text { rasio ini mengukur dimana } \\
\text { suatu unit mampu menarik } \\
\text { pelanggan baru untuk } \\
\text { kepentingan perusahaan }\end{array}$ & $\begin{array}{l}\text { semakin besar total perhitungan } \\
\text { semakin besar pendapatan } \\
\text { perusahaan dalam menghasilkan } \\
\text { laba. }\end{array}$ \\
\hline $\begin{array}{l}\text { Customer } \\
\text { Retention }\end{array}$ & $\begin{array}{l}\text { mengukur tingkat dimana } \\
\text { perusahaan dapat } \\
\text { mempertahankan demakin kecil perhitungan dapat } \\
\text { hubungan dengan } \\
\text { konsumen }\end{array}$ & $\begin{array}{l}\text { dikatakan semakin rendah } \\
\text { hubungan perusahaan dengan } \\
\text { konsumen. Ini mengakibatkan } \\
\text { penurunan pada laba perusahaan. }\end{array}$ \\
\hline
\end{tabular}

a. Customer acquisition = $\frac{\text { jumlah pelanggan baru }}{\text { total jumlah pelanggan }} \times 100 \%$

$2014=\frac{16.144}{65.576} \times 100 \%=24,6 \%$

$2015=\frac{4.752}{9.081} \times 100 \%=52,3 \%$

$2016=\frac{138.804}{208.206} \times 100 \%=66,7 \%$

Pada pergitungan di atas berdasarkan peniingkatan jumlah fasilitas jumlah jaringan pelanggan adalah pada tahun 2014 mencapai
24,6 \% dari tahun sebelumnya, namun pada tahun 2015 menurun menjadi $52,3 \%$ dan meningkat kembali pada tahun 2016 sebesar 66,7\%.

Berdasarkan pada perhitungan yang telah dilakukan di atas mengenai perspektif pelanggan berdasarkan rumus customer acquisition berikut adalah perhitungan keuangan yang telah di rangkum menggunakan table sehingga memper mudah dalam memahaminya.

Table 8

Perhitungan Perspektif Pelanggan Menggunakan customer aquisition PT Sarana Gadai Prioritas Musi Banyuasin Tahun 2014-2016

\begin{tabular}{|c|c|c|c|}
\hline Tahun & Pelanggan Baru & Jumlah Pelanggan & $\begin{array}{c}\text { Customer Acquisition } \\
(3)=(2):(1)\end{array}$ \\
\hline 2014 & 16.144 & 65.576 & $24,6 \%$ \\
\hline 2015 & 4.752 & 9.081 & $52,3 \%$ \\
\hline 2016 & 138.804 & 208.206 & $66,7 \%$ \\
\hline
\end{tabular}

Dari perhitungan tersebut dapat kira lihat bahwa padah 2016 pelanggan meningkat pesat di karenakan pada tahun tersebut pelanggan yang melakukan gadai terutama pelanggan baru meningkat dari tahun sebelumnya ini mengakibatkan kenaikan jumlah pelanggan yang berdampak positif bagi perusahaan, ini berarti hubungan antara konsumen dan perusahaan berjalan baik.

b. Customer retention = $\frac{\text { jumlah pelangga lama }}{\text { total jumlah pelanggan }} \times 100 \%$

$$
\begin{aligned}
& 2014=\frac{49.432}{65.576} \times 100 \%=75,3 \% \\
& 2015=\frac{4.329}{9.081} \times 100 \%=46,7 \%
\end{aligned}
$$




$$
2016=\frac{69.402}{208.206} \times 100 \%=33,3 \%
$$

Dari perhitungan di atas atas customer retention bahwa pada tahun 2014 persentasinya adalah 75,3\%, pada tahun 2015 mengalami penurunan menjadi $46,7 \%$ sampai tahun 2016 juga mengalami penurunan menjadi 33,3\%.

Berdasarkan pada perhitungan yang telah dilakukan di atas mengenai perspektif pelanggan berdasarkan rumus customer retention berikut adalah perhitungan keuangan yang telah di rangkum menggunakan tabel sehingga memper mudah dalam memahaminya.

\section{Tabel 9}

\section{Perhitungan Perspektif Pelanggan Menggunakan Customer Retention PT Sarana Gadai Prioritas Musi Banyuasin Tahun 2104-2016}

\begin{tabular}{|c|c|c|c|}
\hline Tahun & $\begin{array}{c}\text { Jumlah Pelanggan } \\
\text { Lama }\end{array}$ & $\begin{array}{c}\text { Total Jumlah } \\
\text { Pelanggan }\end{array}$ & $\begin{array}{c}\text { Customer } \\
\text { Retention } \\
(3)=(2):(1)\end{array}$ \\
\hline 2014 & 49.432 & 65.576 & $75,3 \%$ \\
\hline 2015 & 4.329 & 9.081 & $46,7 \%$ \\
\hline 2016 & 69.402 & 208.206 & $33,3 \%$ \\
\hline
\end{tabular}

Sumber : PT Sarana Gadai Prioritas Musi Banyuasin di olah tahun 2017

Dari pernyataan di atas bahwa pada tahun 2016 pelanggan lama mengalami penurunan itu karena pada tahun tersebut pelanggan baru banyak melakukan transaksi gadai baru dibandingkan gadai ulang untuk pelanggan lama, begitupun tahun 2015 yang mengalami penurunan dari tahun 2014.

\section{c. Perspektif Proses Bisnis Internal}

Merupakan rangkaian aktivitas yang digunakan oleh pihak untuk menghasilkan produk dan jasa bagi nasabahnya, PT Sarana Gadai Prioritas Musi Banyuasin mengukur kemampuan perusahaan untuk mengidentifikasi segmen pasar yang menguntungkan, mengembangkan produk baru, dan memberikan layanan kepada customer secara efisien dan tepat waktu serta memuaskan. Sasaran strategi yang ingin dicapai dengan penilaian kinerja perspektif proses bisnis internal adalah :

1. mengembangkan produk-produk unggulan
2. meningkatkan pemanfaatan tekhnologi informasi dan perluasan jaringan

Adapun tolak ukur yang tepat digunakan untuk mnegukur keberhasilan dalam perspektif proses bisnis internal adalah :

a) Inovasi

PT Sarana Gadai Prioritas Musi Banyuasin terus melakukan inovasi produk jasa layanan simpan pinjam yang ditawarkan kepada nasabah, dan untuk menciptakan pangsa pasar yang lebih luas dengan memberikan wawasan kepada calon nasabah.

b) Operasi

Untuk mempelancar kegiatan operasinya dan sekaligus meningkatkan pelayanan kepada nasabah PT Sarana Gadai Prioritas Musi Banyuasin memperluas jaringan distribusinya melalui pembukaan cabangcabang, dan menjalankan kerja sama dengan instansi-instansi terkait dan kantor pos dalam 
melakukan pemotongan angsuran agar lebih mudah nasabah dalam melakukan transaksi.

c) Administrative Expense To Total Revenue (AETR)

lalah rasio yang bertujuan mengetahui efisisensi dak efektivitas serta ketetapan waktu proses atas transaksi yang dilakukan PT Sarana Gadai Prioritas Musi Banyuasin.

$\mathrm{AETR}=\frac{\text { biaya administrasi }}{\text { total pendapatan }} \times 100 \%$

$2014=\frac{788,171,787}{26,421,115,391} \times 100 \%=3,00 \%$

$2015=\frac{2,114,577,655}{36,675,730,045} \times 100 \%=5,8 \%$

$2016=\frac{4,078,713,497}{317,338,713,465} \times 100 \%=1,3 \%$

Dari perhitungan di atas bahwa pada tahun 2014 AETR 3,0 \% mengalami kenaikan menjadi 5,8 \% pada tahun 2015, dan pada tahun 2016 AETR mengalami penurunan menjadi $1,3 \%$.

\section{3) Perspektif Pembelajaran dan Pertumbuhan}

Perspektif ini dalam Balanced Scorecard merupakan yang menunjang keberhasilan tiga perspektif lainnya. Perspektif pembelajaran dan pertumbuhan merupakan penyediaan infrastuktur bagi tiga perspektif lainnya yang meliputi personel, kapabilitas sistem informasi, dan keselarasan individu dalam perusahaan.

Sasaran strategi yang ingin dicapai dengan kinerja perspektif pembelajaran dan pertumbuhan adalah

a) Meningkatkan profesionalisme pegawai

b) Meningkatkan pengawas dan budaya patuh pada aturan, sehingga berdampak positif terhadap peningkatan kualitas pelayanan nasabah dan berdampak positif pula terhadap peningkatan pendapatan perusahaan.

\section{H. Kesimpulan dan Saran}

1. Kesimpulan

Berdasarkan uraian yang telah dijelaskan sebelumnya tentang Pengukuran kinerja dengan konsep Balanced Scorecard pada PT Sarana Gadai Prioritas Musi Banyuasin, maka dapat ditarik kesimpulan :

a) Pada Perspektif Keuangan, rasio keuangan yang digunakan adalah ROI, ROE, BOPO, dan Curent Rasio. Hasil penelitian ini menunjukkan bahwa PT Sarana Gadai Prioritas Musi Banyuasin dari tahun 2014 hingga tahun 2016 dapat mencapai cost effectiveness dengan menghasilkan laba perusahaan yang optimal. Kinerja pada perspektif keuangan menunjukkan hasil yang cukup baik.

b) Pada Perspektif Pelanggan, pengukuran profitabilitas konsumen mengambarkan seberapa besar keuntungan yang berhasil dicapai perusahaan dari pendapatan jasa yang ditawarkan kepada konsumen pada tahun 2014 sampai 2016 .

c) Pada Perspektif Bisnis dan Internal, PT Sarana Gadai Prioritas Musi Banyuasin memperluas jaringan operasinya dengan cara membuka cabangcabang dan menjaln kerja sama dengan instansi-instansi terkait dan target pasarnya ialah para nasabah yang mempunyai usahausaha baik usaha kecil maupun besar, hal ini bertujuan untuk meningkatkan layanan purna jual dan memberikan tambahan manfaat kepada para nasabah 
agar tetap mempunyai loyalitas terhadap PT Sarana Gadai Prioritas Musi Banyuasin.

d) Pada Perspektif Pembelajaran dan Pertumbuhan, rotasi karyawan di ukur melalui persentasi perputaran karyawan, pengukuran ini bertujuan unruk mempertahankan karyawan potensial yang di miliki oleh perusahaan untuk tetap loyal terhadap perusahaan tempat mereka bekerja. Pada tahun 2014 sebesar 13,533,591, tahun 2015 sebesar 2,719,624, dan 2016 sebesar 3,815,669. Walaupun pada tahun 2015 sempat mengalami penurunan namun di tahun 2016 mengingkat kembali. Itu menunjukan peningkatan yang baik pada produktivitas karyawan atau rotasi karyawan, karena karyawan merupakan salah satu intangible assets yang mempunyai peran penting dalam meningkatkan perkembangan sebuah perusahaan.

\section{Saran}

Dari kesimpulan di atas telah di uaraikan tersebut, ada beberapa hal yang dapat di jadikan pertimbangan bagi pihak manajemen PT Sarana Gadai Prioritas Musi Banyuasin antara lain :

1. PT Sarana Gadai Prioritas Musi Banyuasin perlu menerapkan Balanced Scorecard sebagai pengukuran kinerjanya, agar pengukuran kinerja perusahaan dapat dinilai dengan cara yang tepat dan dapat segera dicari solusi yang terbaik untuk mengatasi permaslahan yng terjadi.

2. Dalam perspektif keuangan, pihak manajemen harus dapat menekan biaya operasional sehingga dapat meningkatkan laba bersih. Salah satu strategi penekanan biaya yaitu menggunakan perencanaan yang tepat dan pembatasan biaya yang di anaggap kurang bermanfaat.

3. Dalam perspektif pelanggan, manajemen harus lebih meningktkan kualitas produk dan jasa layanan dengan baik seperti memberikan suku bunga yang rendah dan selalu memberikan pelayanan terbaik dengan ramah tama agar pelanggan bisa loyal pada perusahaan ersebut.

4. Perspektif bisnis internal, PT Sarana Gadai Prioritas Musi Banyuasin harus meningktkan atau menambah serta meperbarui system informasinya agar tetap meningkatkan dan meperlancar aktivitas Pegadaian, dan mengembangkan pangsa pasar dan memberikan layanan kepada customer secara efektif dan tepat waktu serta memuaskan.

5. Dalam perspektif pembelajaran dan pertumbuhan, pegadaian harus lebih memberikan pelatihan atau seminar baik untuk pelanggan maupun karyawan agar mampu meningkatkan pertumbuhan perkembangan purna jual pada perusahaan.

\section{DAFTAR PUSTAKA}

Benardi dan Russel. 2010. Penilaian kinerja pada system balanced scorecard. Gramedia . Jakarta

Krismiaji. 2011. Sistem informasi akuntansi. Badan penerbit UPP STIM YKPN. Yogyakarta

Mulyadi. 2011. Sistem terpadu pengelolaan kinerja personel berbasis balanced scorecard. 
Badan penerbit UPP STIM YKPN. Yogyakarta

Rangkuti. Freddy. 2011. SWOT balanced scorecard. Badan Penerbit rajawali pers. Jakarta

Rudianto. 2013. Akuntansi Manajemen. Badan Penerbit Erlangga. Jakarta

Sedarmayanti. 2011. Sumber daya manusia dan produktivitas kerja. Penerbit badan mandar maju. Jakarta
Sugiyono. 2010. Metodelogi penelitian bisnis. Penerbit badan Gramedia. Jakarta

Vithzal. Rival. 2011. Sumber daya manusia untuk perusahaan. Penerbit badan PT Raja grafindo persada. Jakarta

Wibowo. 2011. Manajemen kinerja (edisi 4). Badan penerbit rajawali pers. Jakarta 